\title{
Reflecting on the Distance Learning Provision in Dubai Private Schools
}

$$
\text { التثكي في توفير التعلم عن بعد في مدارس دني الخاصة }
$$

Corresponding Author:

Charlotte Dawson;

email:

mrscjdawson@gmail.com

Submitted: January 24, 2021

Accepted: September 30, 2021

Published: January 31, 2022

Production and Hosting by

Knowledge E

(c) Charlotte Dawson, Claire

Heylin. This article is

distributed under the terms of

the Creative Commons

Attribution License, which

permits unrestricted use and

redistribution provided that

the original author and source

are credited.

Managing Editor:

Natasha Mansur

\section{Charlotte Dawson ${ }^{1 *}$, Claire Heylin ${ }^{1}$}

${ }^{1}$ Tampere University of Applied Sciences, Tampere, Finland

\section{ORCID}

Charlotte Dawson: http://orcid.org/0000-0001-8703-8164

Claire Heylin: http://orcid.org/0000-0002-0109-7321

\section{Abstract}

The purpose of this article is to reflect on the online learning offered by Dubai private schools in response to the Covid-19 pandemic. This article considers both positive and negative features of provision, in order to suggest recommendations for future outbreaks. A comprehensive review of literature synthesizes with the results of an online survey. The period of March until July 2020 is referred to as Phase 1 of online learning. Phase 2 covers September and December 2020. The findings show that educators were generally positive toward online learning but have mixed opinions regarding the permanence, opportunities, and approaches of individual schools. Teachers discussed the progression of online learning within their settings and made multiple recommendations for the future including focusing on social-emotional development and well-being, limiting screen time where possible, ensuring Ed-Tech is appropriate for individual needs, and committing to an ongoing evaluation of curriculum adaptation. It was also suggested that schools review their approach to building technological skills, as well as the age in which this area of development is encouraged.

تهدف المقالة إلى الوقوف على التعلم عبر الانترنت الذي تقدمه المدارس الحاصة في إمارة دبي استجابةً لجائحة كوفيد-19. حيث تتناول المقالة كلاً من السات الإيجابية

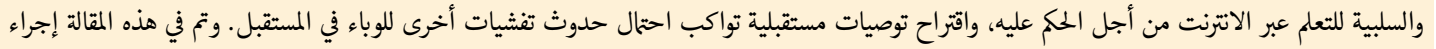

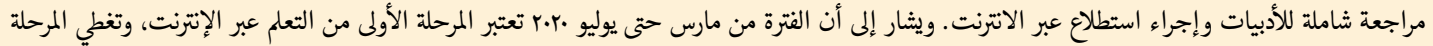

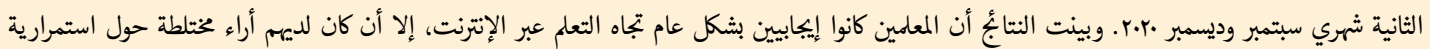

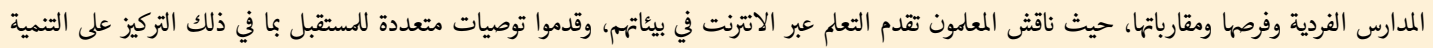

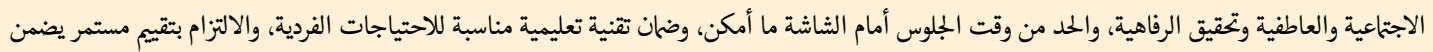

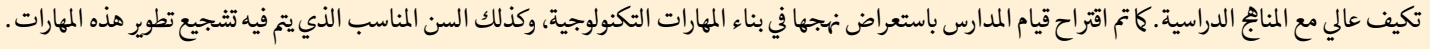

Keywords: Dubai, Online, Learning, Education, COVID-19 


\section{Introduction}

In a global response to the COVID-19 pandemic, many variations of online learning have been implemented by schools around the world. Throughout this article, the term online learning will be used to describe this alternative provision. In the UAE, parents had concerns during the reopening of schools in September 2020 (Sircar, 2020). Families were given the opportunity to choose either face-to-face school attendance or distance learning for their children (Ministry of Education, 2020b). Schools in Dubai implemented statutory reopening protocols (KHDA, 2020c). This led to settings adopting their own educational models for the current academic year, with the aim of offering lessons to students both in-class and at home.

UAE private schools have been under pressure to ensure that the standard of blended learning justify the tuition fees, which have been found to be the second highest in the world (Maceda, 2018). Educational settings, in addition to many other businesses, have had to make budgetary adjustments during the pandemic (Masudi, 2020). In turn, market volatility meant that the UAE could lose around 10\% of its residents (Oxford Economics in Hashmi, 2020). Undoubtedly, this will have a negative impact on staff retention and community well-being, as well as student intake numbers.

During Phase 1 of online learning, the Knowledge and Human Development Authority (KHDA) shared a criteria for assessing the standard of online learning in Dubai private schools. This consisted of three key zones: (1) students' distance learning and well-being; (2) teaching and monitoring students' learning; and (3) leading and managing students' learning (KHDA, 2020a). Two hundred and sixty-seven schools were assessed with this tool and it was found that only one school was considered as "not developed," while 67 schools were "partially developed" and 139 were "developed" (KHDA, 2020b).

Positive features included schools' arrangements for monitoring, assessing, and providing feedback. A similar study conducted by the Ministry of Education (2020a) also found that the key strengths of distance learning programs offered during Phase 1 were: students' attendance rates, knowledge of the concepts of cyber bullying, the need to protect privacy on the Internet, schools' investments in learning resources and teachers' implementation of lessons. Areas for development included ensuring that parents were kept informed regarding the progress of their children, teachers' lesson evaluations, equity of access to learning platforms, development of technical skills, effective participation and interaction of students, and an increased range of learning opportunities (KHDA, 2020b; Ministry of Education, 2020a). 


\section{Methodology}

For this study, data were collected using an online survey, which explored the views of 10 educators $(n=10)$ in various private primary school contexts across Dubai. A qualitative, naturalistic enquiry in the form of a case study was conducted simultaneously by a teacher-researcher during Phases 1 and 2 of online learning. This involved an investigation into the phenomenon in its real-life context (Cohen, 2018). Ethical approval was not required due to research participant anonymity being maintained throughout by omitting identifying information, such as the names of individuals and institutions.

\section{Results}

\subsection{Teacher attitudes}

Findings suggested that $80 \%$ of educators have a positive attitude toward online learning, stating that either they have always been positive about distance learning and the opportunities it presents or that despite initial skepticism, they have now become accustomed to the idea. One educator notes:

Online learning is the way to get children learning and loving learning outside of the physical classroom.

On the other end of the scale, educators commented on the temporary differences online learning made in their setting. One educator expressed their sentiment as:

I don't believe that the opportunities that Distance Learning presents have a permanent value.

A 2008 study found that attitudes toward technology are overwhelmingly positive in schools. Digital tools continue to be implemented despite the initial hesitancy of individual practitioners (Izumi-Taylor, 2008). These findings concur with $89 \%$ of teachers in a similar study, who report that educators support each other in implementing new ideas (OECD, 2019). A strong appreciation of innovation among schools has without a doubt led to many strengths in Dubai's pandemic response.

Bigum and Kenway (2005) suggest that educators fall into four categories concerning the digitalization of education. They categorize some educators as "doomsters" who view technology as a threat to the classroom. Alternatively, there are "anti-schoolers" who reject the concept of formal, institutional learning. "Critics" are not completely opposed to digitalization, but remain skeptical and challenge the assumptions about 


\section{Figure 1}

Teachers' reflection of their experience of online learning during the pandemic

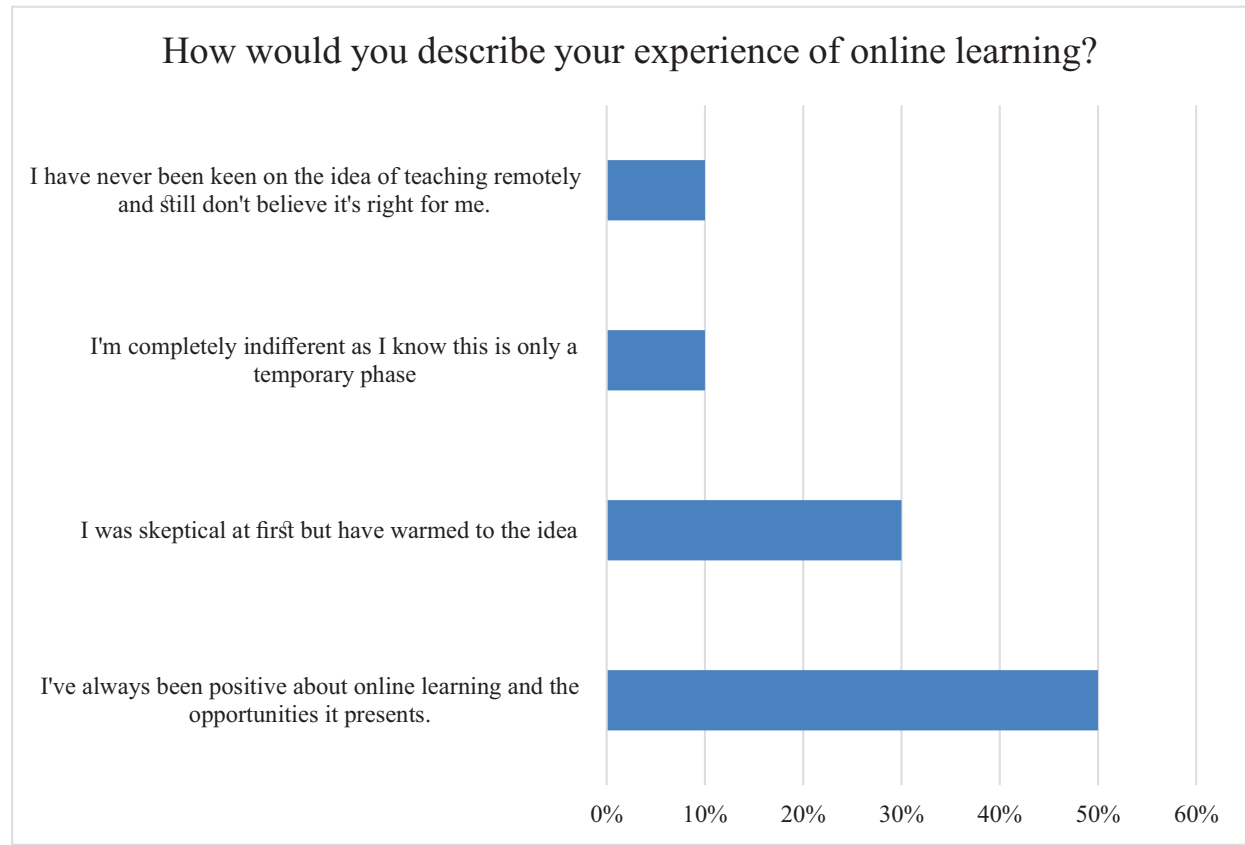

technology in schools. Finally, "boosters" have unswerving faith in digitalization's capacity to improve education. Professional views from all four categories contribute to a grounded perception of technology in schools.

\section{Online learning Phase 1}

During the initial phase of online learning, educators highlighted both positive and negative experiences. Beneficial attributes included: selecting a digital platform, reducing student timetables in order to prioritize key learning points, curricular enrichment such as virtual STEAM weeks, and also training opportunities. Figure $\mathbf{2}$ outlines the commonalities amongst respondents.

About $30 \%$ of the educators believed that the progress of students with additional needs was accelerated during online learning, as one-on-one support was more readily available. Interaction between students and teachers was noted as a positive point, along with reduced behavior management issues and educator relationships. Through blended teaching, students who had traditionally been "under-serviced" gained more direct access to their teacher, school community, and social networks (Hastie et al., 2010, p. 18)

However, other studies have shown that approximately $60 \%$ of teachers in Dubai private schools believed that students with additional needs were not being supported 


\section{Figure 2}

Common themes from survey results with regards to the positive aspects of online learning during the pandemic

\begin{tabular}{|l|l|}
\hline \multicolumn{1}{|c|}{ Positive themes } & \multicolumn{1}{c|}{ Commonalities amongst responses } \\
\hline $\begin{array}{l}\text { Classroom } \\
\text { management }\end{array}$ & $\begin{array}{l}\text { Respondents noted that there were no behavior management } \\
\text { issues during online learning when compared } \\
\text { to the classroom }\end{array}$ \\
\hline Mental health & $\begin{array}{l}\text { Working online gave teachers a sense of purpose when } \\
\text { confined to their homes during a strict lockdown }\end{array}$ \\
\hline Collaboration & $\begin{array}{l}\text { Positive connections with other educators supported teachers } \\
\text { during this experience }\end{array}$ \\
\hline Student support & $\begin{array}{l}\text { Some students received one-on-one support from their parents } \\
\text { accelerating their progress }\end{array}$ \\
\hline
\end{tabular}

enough (Ridge \& Erfurth, 2020). A lack of group work, social skill development and opportunities for building vocabulary and language were also highlighted by survey respondents. A study in online learning concurs with this view: "More often teachers were found less motivated to engage in a deeper-level of social interactions with the distant students" (Zuo et al., 2020, p. 10). It is suggested that the key to success in this area depends largely on teacher facilitation (Zuo et al., 2020). Daniels et al. (2019, p. 6) conclude that teachers most commonly view digital technology as a resource, not considering its "mobility and potential for generating and enhancing young children's communicative practices." This demonstrates a clear need for teacher training and development.A clear link between pupil progress and engagement was acknowledged. However, quantifying learner engagement can be challenging. Dye (2016 in Hofmann, 2018) defines this based on three factors: Emotion, Intellect, and Environment. Students show emotional engagement when teachers involve them in a deeper-level of social interactions, since the teacher acts as the main initiator of classroom discourse (Zuo et al., 2020). In the case of intellectual engagement, educators must ensure that appropriate pace and rigor is applied to the learning outcomes. An environment which is indicative of engagement encourages behaviors inspired by intrinsic motivation (Hofmann, 2018).

Although online teaching reportedly gave a sense of purpose to life during lockdown, the rapid adaptation required in order to create content at short notice was described as "tiring," "time consuming," "stressful," and "exhausting" by survey respondents. Figure $\mathbf{3}$ illustrates the commonalities among respondents. In another study, teachers described the distance learning environment as "more demanding, stressful, and exhausting than regular teaching" (Ridge \& Erfurth, 2020, p. 9). 


\section{Figure 3}

Common themes from survey results with regards to the negatives themes of online learning during the pandemic

\begin{tabular}{|l|l|}
\hline \multicolumn{1}{|c|}{ Negative themes } & \multicolumn{1}{c|}{ Commonalities amongst responses } \\
\hline Social skills & $\begin{array}{l}\text { Teachers voiced concerns about a lack of group work and the } \\
\text { potential adverse effects of this long term }\end{array}$ \\
\hline $\begin{array}{l}\text { Parent } \\
\text { expectations }\end{array}$ & $\begin{array}{l}\text { Parent complaints as parents adjusted to the new online } \\
\text { system }\end{array}$ \\
\hline Teacher workload & $\begin{array}{l}\text { Teachers found the experience exhausting and time- } \\
\text { consuming }\end{array}$ \\
\hline $\begin{array}{l}\text { Lack of adequate } \\
\text { training }\end{array}$ & $\begin{array}{l}\text { Educators had to learn how to adapt to new technologies } \\
\text { without adequate initial training }\end{array}$ \\
\hline
\end{tabular}

There appeared to be a one-size-fits-all approach across some platforms, resulting in an inappropriate selection of such in $30 \%$ of settings, as well as a lack of differentiation. For example, using Class Dojo as a means of manipulating student behavior and storing academic assessment data. This directly relates to the proposed effects of inadequate content and pedagogical considerations; "rushing through the design process at any point could readily result in a failure" (Hofmann, 2018, p. 33). However, little support or guidance was given from leadership teams at $10 \%$ of schools, leaving individual teachers unsure of expectations.

Izumi-Taylor (2008) suggests that, in order to create purposeful and authentic learning experiences, teachers must understand how to implement technology-related activities which are developmentally appropriate. About $10 \%$ of the respondents stated that they were expected to navigate "new platforms with very little support or guidance" provided. Daniels et al. (2019, p. 10) agrees with the need for schools to adapt online learning experiences to the needs of individuals:

What appears to be needed are new ways of understanding the potentiality of children's engagement in digital literacy practices, which demands looking in open-ended and exploratory ways at young children's digitally mediated activity.

Unpleasant experiences reported during this time included the consequences of parent frustration. Ridge and Erfurth (2020) suggest prioritizing support for the most vulnerable groups and providing a space for learning that may not be available at home. Greater parental involvement in education is also encouraged by creating parent support groups, providing more training on how to use online learning platforms and creating closer teacher-parent links to provide support (Ridge \& Erfurth, 2020). "Innovations often fail because of the educators' inability or unwillingness to involve parents in 
meaningful ways in their development and implementation" (Bigum \& Kenway, 2005, p. 20).

There were notable inequalities between students' amount of support at home. Despite many young children being familiar with digital technology, for early years educators, the process of integrating these raises a number of issues and tensions (Daniels et al., 2019). For example, 50\% of the parents surveyed by Ridge and Erfurth (2020, p. 11) reported that their children have to share a room as they engage in distance learning:

For parents with limited space and time, as well as for their children, remote working in combination with distance learning at the same time has proved to be an immense challenge.

A study by Mertala (2017) asserted that today's children fall into three categories in regard to their technological capabilities. The first have been termed as "naturally competent children of invisible parents." These young people have much in common with the description of digital natives (Prenksy, 2001, p. 1) in that they "learn differently compared with past generations of students" (Bennett et al., 2008, p. 2) having spent their lives around technology. Others were seen as "victimized children of victimizing parents" whose high-technology usage came as a consequence of incompetent parenting whereby "parents were thought to lack the skills or the will needed to regulate their children's technology use" (Bennett et al., 2008). The description of "needy children of disadvantaged parents" in turn acknowledged that families' financial situations can cause differences regarding the availability of digital resources (Bennett et al., 2008).

\section{Progression of distance learning in Phase 2}

During the second phase of online learning, schools in Dubai adopted a form of blended learning. The blended model can utilize the best features of face-to-face and online education (Faltýnková, 2020). However, it is also stated that blended learning "is not a one-size-fits-all recipe" (Hofmann, 2018, p. 33) and educators must be ready to adjust and adapt provision according to emerging needs.

Leaders reflected on the experiences of Phase 1 of online learning and decided that the platform selected should be suited to parent, student, and teacher needs. It was also believed that schools now had a greater parent backing than before. Schools either invested in technology provision or operated a "bring your own device" (BYOD) policy. In line with this, teachers also thought more about resources appropriate to both inclass and online learning. The findings of Ridge and Erfurth (2020) support this view and suggest that flexible content and structure is needed in schools. 
Leadership found that it was necessary to focus on staff well-being, as teachers reported that workload doubled since schools reopened and blended classrooms began. Staff faced exhaustion and suggested that lessons should take place either all online or all face to face. Overall, $60 \%$ of the educators felt that the quality of learning subsided in synchronous classrooms; "It got very good very quickly as was necessary. It then slipped back to mediocre once schools could physically open" and "Things changed for the worse with the introduction of dual teaching." For those staff supporting classroom students and distance learners simultaneously, managing workload remains "a massive challenge" (Zaman, 2020). Unfortunately, it has been reported that until now, teacher well-being has been largely unconsidered; "workload, burnout, and emotional loss due to lack of face-to-face dialogue have received little attention" (Zuo et al., 2020).

Moreover, $30 \%$ of teachers felt a lack of confidence in the assessment accuracy of Phase1 and questioned how this could be improved. Ridge and Erfurth (2020) agree that schools should explore diverse assessment methods, including those related to project-based learning. According to Hofmann (2018, p. 33):

The flexible nature of content block design-each block having its own lessons, activities, and assessments-allows the learning experience architect to develop and evolve unique learning paths for different learning personas based on their individual needs.

Power structures such as policy and testing arrangements at micro and macro levels further complicate digital practices (Daniels et al., 2019). Perhaps, as Selwyn (2014, p. 15) suggests, educators should begin to question modes of assessments in their settings by asking: What organizational cultures have formed around the use of data within educational settings, and with what outcomes? and How might data work to be more efficiently and equitably arranged in educational contexts?

About $60 \%$ of those surveyed noted an improved skill set among both teachers and students. This was despite data collected and analyzed by the Al Qasimi Foundation which explored the challenges that students, parents, teachers, administrators faced during the initial period of distance learning. Findings included that $42 \%$ of parents and students had no form of online training from their schools. The study also found that $77 \%$ of teachers had received less than one day of training prior to commencing online learning (Ridge \& Erfurth, 2020). 


\subsection{Teacher recommendations}

Educators emphasized the need for considering the impact of workload on well-being and recognized that blended or online learning should be approached differently to that which takes place in a classroom:

Strip back expectations for both parents and teachers. DL [distance learning] is so intense that it is impossible to maintain a "normal" output of work for stakeholders. Focus on what is important and be lenient.

Reducing students' screen time is also possible when limiting teachers' instruction hours in online classrooms (Ridge \& Erfurth, 2020, p. 15). The sustainability of offering both synchronous and asynchronous lessons was also called into debate.

The needs of both families and schools were considered. Suggestions included "an approach where there is a mix of face-to-face days and distance learning days" and using "a selection of prerecorded videos and live sessions."

All respondents insisted on the use of platforms: "Schools need a virtual learning platform to fall back on;" $50 \%$ of the respondents expanded on this by reiterating the importance of taking students' individual needs into consideration when selecting resources, such as in the following quote from survey respondents; "Age-appropriate platforms should be considered rather than one for all ages across the school." According to Gray and Tobin (2010), teachers' online roles include creating a clear, organized structure, and selecting user-friendly tools. Leaders were requested to analyze the suitability of content for online contexts, with one respondent advising, "Don't be afraid to drop subjects if they are not working." This may lead to curricular adaptation being reflected on going forward, not only within the confines of a pandemic response.

Survey feedback also stated, "In a world where Wikipedia is readily available, knowledge-based curricula can go by the wayside, but skills-based lessons are essential." It is interesting to note that schools adopting the IB curricular were viewed among the most successful. Of the 17 chosen settings, 16 were rated as "developed" (KHDA, 2020a). This would suggest that more progressive schemes of work prioritize skills-based learning over that of knowledge and content.

Furthermore, $30 \%$ of suggestions were targeted specifically toward senior leadership. One educator noted, "School management should provide better support for the staff and pupils. Clear guidelines on expectations for students, parents, and teachers." This view may indicate a lack of confidence in technology and digital learning on the behalf of school management. One solution may be to appoint a digital technology leader, as suggested by survey respondents; "Encourage staff to fully research and recommend 
apps they think are useful to a coordinator who can then recommend them for whole school/Key Stage use."

Central to the role of a technology lead practitioner is the need for a critical attitude toward ed-tech solutions. However, it could be argued that this approach is key for all educators and not only one leader. According to Bennett et al. (2008, p. 10):

As there is a need for a considered and rigorous investigation that includes the perspectives of young people and their teachers, and genuinely seeks to understand the situation before proclaiming the need for widespread change.

This view is also supported by Teräs et al. (2020, p. 7) who argue that:

The current time of pandemic crisis and response is not the most appropriate for making long-term plans or investments in regard to educational technologies. Instead, what is needed is a critical analysis of these matters.

Another point raised was that of a lack of training prior to, or even during, online learning; "Offer online CPD for teachers about how to optimize learning experiences during distance learning and collaborate to share best practice." As technology plays a key role in children's learning and development, educators should know how to develop technological literacy for themselves as professionals (Izumi-Taylor, 2008, p. 14). It is recommended to give teachers time to share good practice with colleagues during periods of online learning (Ridge \& Erfurth, 2020, p. 15).

Moreover, $30 \%$ of the educators mentioned students' lack of digital skills. They suggested that children should be introduced to technology from a young age as explained in the following survey quote; "Build elements of Distance Learning into the Foundation Stage from September onward in order to get pupils and parents familiar with the reality of Distance Learning in FS." This view is reflected by Jack and Higgins (2019, p. 14) who state that there "appears to be a widening gap forming between the skills we teach in schools and those which we require, in order for children to learn in an increasingly digital world." Many educators also note that children need opportunities to experience and explore technology from an early age, in order to prepare them for life in a modern society (Izumi-Taylor, 2008, p. 13).

About $20 \%$ of the survey respondents expand on this view by suggesting that children from the foundation stage become familiar with using technology in class. The overall aim would be to familiarize students with a selection of specific devices and tools in order to enable access to online learning with increasing independence in the future. Jack 
and Higgins (2019) add that it is possible for educational technologies to have more of an impact on teaching and learning, but curriculum documentation must also address this. One study found that while $52 \%$ of early years educators thought technology was essential in their context, just $28.7 \%$ thought that it was necessary to support the curriculum outcomes (Izumi-Taylor, 2008).

In the most recent curriculum documentation for England, educational technology is mentioned only in the "Understanding the World" section; "children recognize that a range of technology is used in places such as homes and schools. They select and use technology for particular purposes" (Department for Education, 2012). As advocated by Prenksy (2001, p. 5), "rethinking needs to be applied to all subjects at all levels" as "technology plays a different role in students' home and school lives" (Bennett et al., 2008, p. 7). Hofmann (2018) explains that in digital contexts, students are not only learning content but also learning how to learn. "If the learning environment is based on-or, even better, uses-a real-world context, the learner develops true competence by participating in the learning experience" (Dye, in Hofmann, 2018, p. 20).

One survey respondent recommended teaching live, online lessons in smaller groups; "Less lessons and more time to talk to children in smaller groups. But then coverage of the curriculum would suffer so it depends on what your school sees as a priority." It is suggested that technologies such as blogs, journals, and discussion boards alongside live lessons can increase student interaction with both peers and the teacher (Tseng and Walsh, 2016). This solution could be tailored to suit diverse age groups and reduce the extensive need for live synchronous sessions; "Children should play and work together in a group-oriented environment through technology-related activities in order to promote their social and emotional development" (Izumi-Taylor, 2008, p. 13). In terms of concerns regarding curriculum coverage, research has associated blended courses with increased student involvement, positive perceptions, and achievement (Antonoglou et al., 2011).

\subsection{Continued skills and tools}

All teachers stated that even once the prescribed distance or blended learning period has ended, they will continue to incorporate some elements of technology into their classrooms. These include platforms and software such as Microsoft Teams and Education Tools, Zoom, Video Scribe, Epic Kids Books, Google Classroom, Surface Pro, and Seesaw. Going forward, educators should expect to demonstrate how to use online tools during face-to-face classes (Zhou et al., 2012). 
Digital technology can be oversimplified and has often been presented simply as a solution to another area of the curriculum (Daniels et al., 2019). About $20 \%$ of survey respondents explained that they had acquired skills as opposed to gaining programspecific experience. Developing "webinar skills" was mentioned, which include limiting distractions during live sessions, anticipating technological issues and how these can be avoided, scripting presentations collaboratively, considering participant interaction, and inserting a greeting slide so that viewers can relate to the person behind the voice (Biech, 2016).

The possibility to share learning and support colleagues, as well as the wider school community, through various mediums was also expressed.

I have definitely found YouTube to be more than a streaming site for videos! I have 3/4 of my lessons on there now, not just for myself, but also to share with parents and teachers who need more support with subject ideas.

This comes as schools are urged to encourage an increased amount of parental involvement in children's education (Ridge \& Erfurth, 2020). The period of online learning has encouraged teachers to reflect on the future of homework. Educators now consider how tasks are documented, shared, and responded to "Activities on seesaw both in class and for homework." The concept of flipped learning also emerged; "Creative homework projects which give 'nonacademic' students a chance to show what they can do." This strategy utilizes the learning benefits of both online and face-to-face teaching by removing pure knowledge content from the classroom and making it available online (Sharples et al., 2014, p. 15). It also assists students in having more control and responsibility for their learning.

\section{Conclusion}

Schools should continue to prepare for ongoing or future outbreaks (Ridge \& Erfurth, 2020) and have been advised to prepare by creating emergency learning kits, delivering printed resources where necessary, continuing to invest in e-learning resources and to have an emergency fund for maintaining liquidity during crisis periods (Ridge \& Erfurth, 2020). It is recommended that further investigation be carried out in regard to successful school leadership strategies during this time, in addition to the resulting influence of such.

Survey respondents' recommendations for future Distance Learning Programs fit into three main categories. Overall, $40 \%$ of the respondents said that schools needed age-appropriate platforms, potentially differing by key stage. A platform most suited 


\section{Figure 4}

Recommendations by survey respondents for future Distance Learning Programs

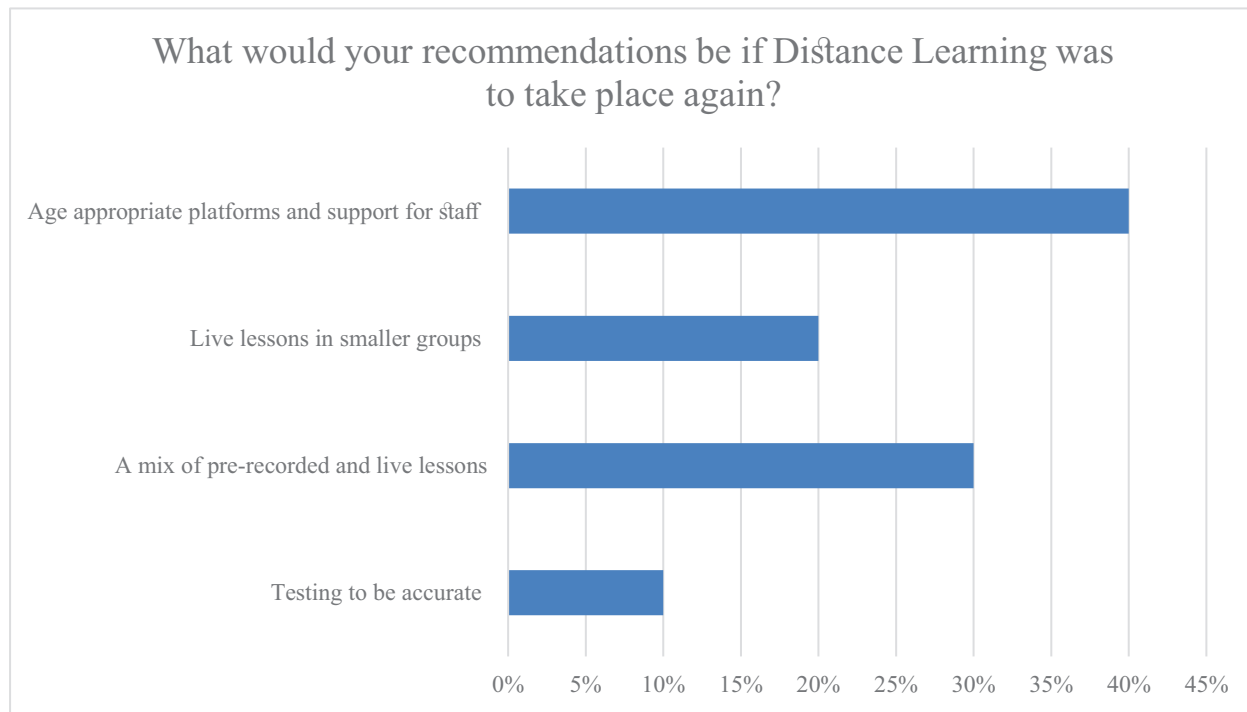

to Foundation Stage may not suit Key Stage 1 but this should not deter school leaders. It was also suggested that schools have a digital learning leader who staff could turn to for support when embarking on distance learning programs. A mix of prerecorded and live lessons was suggested by $30 \%$ of the respondents with $20 \%$ saying live lessons should be in smaller groups to enhance interactions with children.

It is important to emphasize the potential impact of continued reflection, particularly as schools attempt to navigate new and unfamiliar ways of working. This applies to both leaders and teachers. An example of successful integration of evaluation and application into an organization can be found in the Critical Applied Research of Digitalization in Education (CARDE) group's manifesto. Composed of a team from diverse, international backgrounds, these educators seek to: engage people, networks, projects, and research; apply and develop critical applied research methodologies; create design principles for democratic and emancipatory research and development of digitalization; evoke dialogue through communication with a wider public using clear, inclusive language; and also promote new approaches to research and development publishing (Tampere Universities, 2020).

The Analyze, Design, Develop, Implement, Evaluate model should be adopted when developing an online learning campaign (Hofmann, 2018). To begin, authentic approaches to educators' skill development should be considered. During the design phase, measurable outcomes should be identified and completion deadlines be assigned. "Social collaboration should be part of any blended learning initiative" (Hofmann, 2018, p. 39). It is important to identify the experts to consult when developing 
a program, and set aside time for learning. Evaluation should be carried out regularly and educators should be open to the idea of direction changing purposefully. A platform which has proven especially useful for this purpose throughout the COVID-19 response has been the evolution of Edu Twitter, especially the CollabUAE group of practitioners.

Before creating an evaluation plan, designers must consider what they envisage a successful learning program to look like. In order to reflect effectively on this, an initial needs assessment should have uncovered "the needs of the organization, the gaps between current and desired performance, and what learners already know about the topic." If this information has not been thoroughly documented, it will be impossible to identify what to evaluate and what is missing (Hofmann, 2018, p. 15).

\section{Acknowledgements}

The authors would like to thank the Critically Applied Research of Digitalization in Education (CARDE) group and the Educational Leadership team at Tampere University of Applied Sciences.

\section{Funding Information}

No funding provided.

\section{Competing Interests}

The authors have no competing interests to declare.

\section{Author Biography}

Charlotte Dawson graduated with a BEd in Primary Education in 2011 and has worked in schools across the United Arab Emirates since 2011. She has taken up both teaching and leadership roles in the region. Charlotte graduated from the Educational Leadership program at Tampere University of Applied Sciences in 2020 and continues to write as an affiliated member of the CARDE research group. Within the field of educational research, her key interests are the areas of leadership philosophy, environmental education and curriculum development.

Claire Heylin completed a Post Graduate Diploma in Education (Primary Teaching) in Ireland in 2010 and has taught in the UAE since 2015. She has worked in both teaching 
and leadership roles in Dubai. Claire is studying an MBA in Educational Leadership through Tampere University, Finland. Her areas of interest in education are Early Years, Learning through Play and Literacy.

\section{References}

[1] Antonoglou, L. D., Charistos, N. D., \& Sigalas, M. P. (2011). Design, development and implementation of a technology enhanced hybrid course on molecular symmetry: Students' outcomes and attitudes. Chemistry Education Research Practice, 12(4), 454-468. https://doi.org/10.1039/c0rp90013c

[2] Bennett, S., Maton, K., \& Kervin, L. (2008). The 'digital natives' debate: A critical review of the evidence. British Journal of Educational Technology, 39(5), 775-786. https://doi.org/10.1111/j.1467-8535.2007.00793.x

[3] Biech, E. (2016). 101 ways to make learning active beyond the classroom (1 ${ }^{s t}$ ed.). Wiley.

[4] Bigum, C., \& Kenway, J. (2005). New information technologies and the ambiguous future of schooling - Some possible scenarios. In A. Hargreaves (Ed.), Extending educational change: International handbook of educational change $\left(2005^{\text {th }}\right.$ ed.) Springer.

[5] Cohen, M. (2018). Research methods in education. In L. Cohen, L. Manion, \& K. Morrison (Eds.), Research methods in education ( $8^{\text {th }}$ ed., vol. 1). Routledge. https://doi.org/10.4324/9781315456539

[6] Daniels, K., Bower, K., Burnett, C., Escott, H., Hatton, A., Ehiyazaryan-White, E., \& Monkhouse, J. (2019). Early years teachers and digital literacies: Navigating a kaleidoscope of discourses. Education and Information Technologies, 25(4), 24152426. https://doi.org/10.1007/s10639-019-10047-9

[7] DfE. (2012). Development matters in the Early Years Foundation Stage (EYFS). The British Association for Early Childhood Education. https://www.foundationyears.org.uk/files/2012/03/Development-Matters-FINALPRINT-AMENDED.pdf

[8] Faltýnková, L. (2020). Blended versus traditional learning: Comparing students' outcomes and preferences. In S. Cheung, R. Li, K. Phusavat, N. Paoprasert, \& L. Kwok (Eds.), Blended learning. Education in a smart learning environment. ICBL 2020. Lecture notes in computer science, 12218, 276-286. https://doi.org/10.1007/978-3030-51968-1_23 
[9] Gray, K., \& Tobin, J. (2010). Introducing an online community into a clinical education setting: A pilot study of student and staff engagement and outcomes using blended learning. BMC Medical Education, 10(6), 1-9. https://doi.org/10.1186/1472-6920-10-6

[10] Hashmi, B. S. (2020, October 9). Coronavirus threatening expat exodus from the UAE. BBC News. https://www.bbc.com/news/world-middle-east-54418336

[11] Hastie, M., Hung, I.-C., Chen, N.-S., \& Kinshuk. (2010). A blended synchronous learning model for educational international collaboration. Innovations in Education and Teaching International, 47(1), 9-24. https://doi.org/10.1080/14703290903525812

[12] Hofmann, J. (2018). Blended learning. Association for Talent Development.

[13] Izumi-Taylor, S. (2008). Play and technology in group-oriented Japanese early childhood educational settings. He Kupu. The Word, 1(4), 1-7. Retrieved from https://www.hekupu.ac.nz/sites/default/files/2017-11/Play\%20and\%20Technology\%2 Oin\%20Group-Oriented\%20Japanese\%20Early.pdf

[14] Jack, C., \& Higgins, S. (2019). Embedding educational technologies in early years education. Research in Learning Technology, 27(0), 1. https://doi.org/10.25304/rlt.v27.2033

[15] KHDA. (2020a). Distance learning evaluation tool. Retrieved from https://www.khda.gov.ae/CMS/WebParts/TextEditor/Documents/Distance-LearningEvaluation-Tool-English.pdf

[16] KHDA. (2020b). Distance learning profiles of Dubai private schools: Evaluation results 2020. Retrieved from https://www.khda.gov.ae/DLEreport/DLEReports.aspx

[17] KHDA. (2020c). Protocols for the reopening of private schools in Dubai. Retrieved from https://www.khda.gov.ae/CMS/WebParts/TextEditor/Documents/SchoolsReopening-Protocol-En.pdf

[18] Maceda, C. (2018, October 29). UAE school fees 'second highest in the world': HSBC study. Gulf News. https://gulfnews.com/how-to/your-money/uae-school-fees-secondhighest-in-the-world-hsbc-study-1.2052333

[19] Masudi, F. (2020, June 21). UAE premium schools most at risk of losing students, experts warn. Gulf News. https://gulfnews.com/uae/education/uae-premium-schoolsmost-at-risk-of-losing-stud ents-experts-warn-1.72153597

[20] Mertala, P. (2017). Wonder children and victimizing parents - Preservice early childhood teachers' beliefs about children and technology at home. Early Child Development and Care, 189(3), 392-404. https://doi.org/10.1080/03004430.2017.1324434

[21] Ministry of Education. (2020a). Ministry of Education concludes the evaluation of the distance learning program in public and private schools. MoE. https://www.moe.gov.ae/En/MediaCenter/News/Pages/DLSE20.aspx 
[22] Ministry of Education. (2020b). 2020-2021 academic year to begin on August 30. MoE. Retrieved from https://www.moe.gov.ae/En/MediaCenter/News/Pages/attendence20.aspx

[23] OECD. (2019). TALIS 2018 country note - United Arab Emirates. Retrieved from http://www.oecd.org/countries/unitedarabemirates/

[24] Prenksy, M. (2001). Digital natives, digital immigrants part 1. On the Horizon, 9(5), 1-6.

[25] Ridge, N. Y., \& Erfurth, M. (2020). The impact of Covid-19 on education in the UAE (Strategic Report No. 1). Sheikh Saud bin Saqr AI Qasimi Foundation for Policy Research. http://dx.doi.org/10.18502/aqf.0143

[26] Selwyn, N. (2016) 'Minding our language: why education and technology is full of bullshit... and what might be done about it', Learning, Media and Technology, vol. 41, no. 3, pp. 437-443. doi: 10.1080/17439884.2015.1012523

[27] Sharples, M., Adams, A., Ferguson, R., Gaved, M., McAndrew, P., Rienties, B., Weller, M., \& Whitelock, D. (2014). Innovating pedagogy 2014: Open university innovation report 3. Milton Keynes: The Open University.

[28] Sicar, N. (2020, July 26). Back to campus: Schools in Dubai offer e-learning to worried parents. Khaleej Times. https://www.khaleejtimes.com/coronavirus-pandemic/backto-campus-schools-offer-e-learning-to-worried-parents

[29] Tampere University of Applied Sciences. (2020). New research group established: Critical Applied Research of Digitalization in Education (CARDE). Critical Applied Research of Digitalization in Education (CARDE). Retrieved from https://research.tuni.fi/carde/news/new-research-group-established-critical-appliedre search-of-digitalization-in-education-carde/

[30] Teräs, M., Suoranta, J., Teräs, H., \& Curcher, M. (2020). Post-Covid-19 education and education technology 'solutionism': A seller's market. Post Digital Science and Education, 2(3), 863-878. https://doi.org/10.1007/s42438-020-00164-x

[31] Tseng, H., Walsh, E. J. (2016). Blended versus traditional course delivery: Comparing students' motivation, learning outcomes, and preferences. The Quarterly Review of Distance Education, Volume 17(1), 2016, (pp. 43-52).

[32] Zaman, S. S. R. (2020, October 9). COVID-19: UAE students and educators discuss how it feels to be back, a month into the new term. Gulf News. https://gulfnews.com/uae/education/covid-19-uae-students-and-educators-discuss-h ow-it-feels-to-be-back-a-month-into-the-new-term-1.74432871

[33] Zuo, M., Yan, Y., Wang, K., \& Luo, H. (2020). What drives rural students' behavioral engagement in synchronous online classrooms? Examining the effects of discourse interaction and seating location. In S. Cheung, R. Li, K. Phusavat, 
N. Paoprasert, \& L. Kwok (Eds.), Blended learning. Education in a smart learning environment. ICBL 2020. Lecture notes in computer science, 12218. Springer, Cham. https://doi.org/10.1007/978-3-030-51968-1_20 